\title{
Microbial assessment of potential functional dairy products with added dried herbs
}

\author{
Kármen Anita Kiss - Viktória Kapcsándi - Rebeka Ligeti - Erika Hanczné Lakatos \\ Institute of Food Sciences, MÉK Faculty of Agriculture and Food Sciences, Széchenyi István University, Hungary \\ kiss.karmen.anita@sze.hu
}

SUMMARY

\begin{abstract}
The market of dairy products is a dynamically developing sector of the food industry. Potential, functional dairy products, made by adding herbs or spices, will have antimicrobial and antioxidant effect due to the active biochemical agents of the plant additives. Furthermore, these active components will widen the storage life of food products and enhance their organoleptic properties too. We worked out a technology for creating fresh cheeses using a gentle pasteurizing method by treating the mixture of raw milk and $1.5 \%$ fat contained in commercial milk. As herb additives, we used citronella (Melissa officinalis), and peppermint (Mentha x piperita) harvested by us and dried them via Tyndall-method in convective dryer on $40{ }^{\circ} \mathrm{C}$ for 5.5 hours per day. The drying period took three days. We bought dried citronella and mint from the supermarket, which were dried by ionizing radiation, to compare the microbiological pollution with the herbs dried by us.

The main target of this research was to create a microbiologically stable, potential functional dairy product. However, because of the bad quality of the raw milk and the gentle heat treatment we used for sterilizing bulk milk, or else, cheeses were not safe for human consumption. As a consequence, we need further studies to modify our technology and get a microbiologically stable product.
\end{abstract}

Keywords: dried herbs, mint, citronella, functional food, cheese

\section{INTRODUCTION}

The health care was developing with our history. The herbs and spices always had an essentiant role in curing or prevent different diseases. Nowadays the consumers prefer food, in which natural chemical components replace synthetic materials. Herbs and spices natural antioxidant and antimicrobial effects, so they take part not only in flavouring or are alternative resource of salt, but they are capable of maintaining our health (European Parliament and Council, 2008; Shan et al., 2001).

The extracts of herbs and spices have several biochemically active compounds. Using them as a natural additive in the food industry, they can widen the storage life by eliminating the spoilage or pathogen microorganisms or reducing their numbers under the limit was determined in the Decree 4/1998 (XI.11.) EüM. (4/1998 (XI.11.) EüM; Chua et al., 2019).

With the growing population of functional foods, the demand for herbs and spices has increased. Lemon grass (Melissa officinalis) is a member of Lamiaceae and is a native herb in Southern-Europe and NorthAmerica. Its leaves contain a relatively small amount of essential oil, and the extraction process of lemon balm is expensive. This herb has antispasmodic, hepatoprotective, carminative, anticarcinogenic and antiviral effects. The main biochemical component of lemon balm is citral. (Ghasemi et al., 2013; MimicaDukic, 2004).

Peppermint (Mentha x piperita) is a member of Labiatae and after the citrus and vanilla, the most widely used flavouring component of the world. It grows in the temperate climate parts of America, Europe and Asia. All species of mint are rich in minerals. Their essential oil's main components are carvone, limonene and eucalyptol (1, 8-cineole). Mint is an effective and long used preservative; furthermore, it can be used against flu, colds, motion sickness, and digesting problems (Arslan et al., 2010; Díaz-Maroto et al., 2003; Rubinskiené et al., 2015; Therdthai and Zhou, 2009).

The herbs are preserving by reducing their moisture content using different drying methods. The most commonly used is sun drying, but until the herbs stay rich in colour and aromatic components, the drying procedure is slow. Not to mention that the quality of the final product is affected by weather and ambient pollution (Rocha et al., 2011).

The convective drying can shorten the duration of sun drying, and besides, less space is required. We can carry out the drying process between controlled conditions (ambient temperature, drying time, relative humidity, etc.). In the convective drying, the water transferred from the interior to the surface of the material, because of the increasing ambient temperature. At the same time, this water will evaporate and transport the vapour by vacuum or hot air. This process is driven by the moisture concentration gradient (Rocha et al., 2011).

The temperature, the method and the time of drying, significantly affect the quality of the dried material. The recommended drying temperature by convective drying of lemon grass is about $40^{\circ} \mathrm{C}$, and for mint, the most optimal value is $50{ }^{\circ} \mathrm{C}$ according to the referring literature (Borbélyné and Kutasy, 2012; Ghasemi et al., 2013; Rocha et al., 2011). $30^{\circ} \mathrm{C}$ is the most optimal for preserving the colour of the dried herbs. However, this temperature won't be high enough to eliminate the foodborne pathogens or spoilage microorganisms. With the increase of the drying temperature, the time of drying could be shortened, but it also could cause some change in the chemical structure of the active components of herbs (Rubinskiené et al., 2015; Therdthai and Zhou, 2009). 
The sector of dairy products pays the most attention to create functional foods with herb additives. Its wide product range allows them to spread the so-called "natural" food products. These contain only a small amount of synthetic additives or none of them at all (ElSayed and Youssef, 2019; Lee et al., 2016).

The production of cheeses shows an increasing tendency since 2000 all around the world. These products mean $25 \%$ of the dairy products. The main target of using herbs and spices by creating cheeses was to increase their self-life. The most common chemical components of herbs, like carotenoids, terpenoids and phenolic compounds inhibit the unnecessary enzymatic reactions and the growth of pathogen microorganisms (Aschwanden, 2001; Granato et al., 2018; Lee et al., 2016; PM Food and Dairy Consulting, 2014).

The aim of this research was to create new potential, functional dairy product using the technology, we worked out and addicting them with the herbs (lemon grass and mint) we dried according to Tyndall and purchased commercially.

\section{MATERIALS AND METHODS}

By the microbiological measurements, growth media from Biolab and Merck were used, the incubation of the samples and the final products were carried out in BINDER 720 thermostat. The milk was pasteurized in stainless steel pan on an electric ceramic hob (FIRST Austria 5095-1). To optimize the milk's calcium content and avoid bloating, $\mathrm{CaCl}_{2}$ (Molar Chemicals Inc.) and $\mathrm{KNO}_{3}$ (Tetra Chemicals Europe $\mathrm{AB})$ and by the production of cheeses, we used $\mathrm{CHY}$ MAX rennet (CHR Hansen) and FD-DVS CHN-22 mesophilic aroma forming culture (CHR Hansen) were used. The cheeses were packaged using micro-vacuum technology (GOURMET N70) with nitrogencontaining shielding gas. Each of the cheese and herb samples were homogenized by Stomacher Homogenizer for the microbial measurements.

\section{Examination of antibiotic effect of herbs}

From the raw lemon grass and peppermint, 2.5-2.5 $\mathrm{g}$ of samples were taken and then diluted with nine-time amount of sterile diluting water. For the disk-diffusion agar test, ATCC®10149 kit was used.

\section{Drying of herbs}

During our research, we were using two types of drying methods to reduce the moisture content of the selected herbs. Our first drying method didn't decrease the moisture content of the samples under 10-14\%, we needed to use the Tyndall-method to earn the appropriate value.

The dry matter and moisture content from raw peppermint and lemon grass harvested by us were determined in convective dryer. 1-1 g was used to three drying cups per herb and adding $30 \mathrm{~g}$ of diatomaceous to every of the raw plant samples, which were previously chopped in a mortar. The samples were drying on $105^{\circ} \mathrm{C}$ for 1.5 hours and then left them to cool down in an excitatory. After the drying, the moisture content of the raw herbs was measured.

According to our experiences, the mass of the dried herbaceous leaves will be about one-sixth or oneseventh of the mass of the raw material. We needed to get $30 \mathrm{~g}$ of dried herb leaves after the convective drying, so $180 \mathrm{~g}$ of lemon grass and the same amount of peppermint leaves were measured, then spread in thin layer on a perforated tray. The drying was carried out in the convective dryer, at $40^{\circ} \mathrm{C}$ for 5.5 hours.

Drying according to the Tyndall-method, the samples were dried between the same parameters, as it was used previously. The difference was that the drying procedure has been repeated during three consecutive days. In this case, a larger amount of herbs were measured (about 250-300 g).

\section{Production of cheeses}

Since our last research, we rewrite our technology for creating fresh cheeses. After determining the fat content of the raw milk and the $1.5 \%$ fat contained commercially bought milk using Gerber-method, they were mixed applying the correct mixing ratio equation to get a $2.9 \%$ fat contained, bulk milk.

The bulk milk was pasteurized on an electric ceramic hob on maximum performance value, using water bath to transfer the heat to the stainless steel pan. Thus, the milk didn't receive the heat directly from the heat source. When the milk reached the $72{ }^{\circ} \mathrm{C}$ temperature value, the pan was removed from the water bath without using holding time. The $\mathrm{pH}$ value of the milk was measured at $47^{\circ} \mathrm{C}$ and $72{ }^{\circ} \mathrm{C}$, and the $\mathrm{pH}$ value was 6.6.

This time, $7 \mathrm{~L}$ of pasteurized, $2.9 \%$ fat contained milk was used as raw material for cheese making. After the stainless steel pan was removed from the water bath, it was left to cool down. At the temperature of $40{ }^{\circ} \mathrm{C}, 0.7 \mathrm{~g} \mathrm{KNO}_{3}, 0.7 \mathrm{~g} \mathrm{CaCl}_{2}$ and $0.14 \mathrm{~g} \mathrm{FD-DVS}$ CHN-22 culture of mesophilic, aroma forming milkacid bacteria (Lactococcus lactis subsp. cremoris, Lactococcus lactis subsp. lactis, Leuconostoc mesenteroides subsp. cremoris and Lactococcus lactis subsp. lactis biovar diacetylactis) were added. The culture was solved in 4-6 mL milk, which was removed from the pasteurized milk, and only after this step could we added the culture to the milk. $11 \mathrm{~mL}$ sample was taken from the treated milk for determining the final fat contain our mixture, and it was $2.9 \%$, as it was calculated it before. Furthermore, $2.5 \mathrm{~mL}$ of pasteurized, bulk milk was used for the determination of Salmonella spp. When the mixed milk cooled down until $35^{\circ} \mathrm{C}, 2.5 \mathrm{~mL} \mathrm{CHY}-\mathrm{MAX}$ rennet was added to it. After this, the mixture was left to coagulate. The coagulating took 36 minutes, and the $\mathrm{pH}$ value of the curd was 6.4. The temperature of the system was kept at $35^{\circ} \mathrm{C}$.

The plastic cheese mould baskets and the harps were sterilized by immersed into hot water. After that, the curd was cut with the harps to get nut sized curd parts. Then the curd was heated for $40{ }^{\circ} \mathrm{C}$, to make it easier to remove the whey using plastic whey-filter. 
After that, $3 \%$ of salt was added to the curd. The amount of salt was calculated to the amount of curd. $140 \mathrm{~g}$ of salted curd was measured in plastic moulds (200 g capacity) and mixed the herbs to the separated mould baskets. In the end, there were five pieces of cheeses, $0.5 \%$ of herbs were mixed to them, calculating to the cheese's mass. I one of them lemon grass and into another peppermint was added, which was dried by us according to Tyndall-method. Two of the cheeses was added by the same dried herbs, but these were bought by us, dried by the industry, using ionizing radiation. One blank cheese (without plant) was used as a control to our measurements.

During this production process, no pressuring was used. The cheeses were left to release whey by their own weight in the moulds. Each product was sampled for microbial assessments. Eventually, the cheeses were cut into three parts, then packed separately, using nitrogen shielding gas packaging technology.

Microbiologically measurements of milk and herbs

After the homogenization, $1 \mathrm{~cm}^{3}$ was taken from the raw, convective dried and Tyndall-dried and the commercial, ionized radiation dried lemon grass and peppermint samples, from the pasteurized, bulk milk, the salted and formed fresh cheeses too into Petri dishes. After that, Plate Count (Biolab PC - total cell count), Chromocult Coliform (Merck CC - coliform and E. coli), Yeast Extract Glucose Chloramphenicol (Biolab YGC - mould and yeast) media were plated on them. In the case of Baird Parker (Merck BP) agar, 0.1 $\mathrm{cm}^{3}$ sample was superficially spread on pre-cast solidified media. Samples on PC media were incubated 72 hours at $30{ }^{\circ} \mathrm{C}$, on CC 24-48 hours, on YGC 96 hours at $26{ }^{\circ} \mathrm{C}$, and on BP media 24-48 hours incubation at $37{ }^{\circ} \mathrm{C}$ was used.

The dried plant samples and the pasteurized milk were also tested for the presence of Salmonella spp. on Xylose Lysine Deoxycholate (Biolab XLD agar), incubated at $37{ }^{\circ} \mathrm{C}$, serotyped with O-antigen, and mesophilic spore-forming bacteria (on Tryptose Sulfite Cycloserine agar, Merck TSC; $37^{\circ} \mathrm{C}$ ).
In our microbiological examinations, we took into account the microorganism groups defined in Decree 4/1998 (XI.11.) EüM and compared our results with the values of the decree for pasteurized milk, dairy products (cheese) and dried herbs. The results were obtained by subjective colony count and then weighted mean method for averaging bacterial count $(\dot{C})$, expressed in $\mathrm{CFU} \mathrm{g^{-1 }}$. Plates with colonies between 10 and 300 were included in the evaluation. The values were compared with those one, which are specified in decree aforementioned (4/1998 (XI.11.) EüM).

\section{RESULTS AND DISCUSSION}

The main target of our research was creating potential, functional cheese products using medical herbs (lemon grass and peppermint) dried by us. For the microbial safety of herbs, their moisture content needs to be lowered under $10-14 \%$ MC. The dry matter content using the convective drying method for 5.5 hours at $40{ }^{\circ} \mathrm{C}$ was $71.51 \%$ in case of lemon grass and $67.15 \%$ of peppermint. This means that the moisture content (lemon grass $28.49 \%$, peppermint $32.45 \%$ ) of the plants were higher, than the recommended value for the safety shelf-life for herbs.

We needed to use Tyndall-method to earn the optimal moisture content of the selected herbs. The drying was carried out for three days with the same drying temperature and time. As a result of this process, our samples mean moisture content decreased under $10 \%$ (lemon grass $8.2 \%$, peppermint $9.0 \%$ ). This drying method was capable to ensure that moisture value, which was written in the referred literature. (Borbélyné and Kutasy, 2012)

During this assessment, our first aim was to compare the microbial stability of the commercially purchased lemon grass and peppermint and the same herbs, in raw and dried form. First, we checked the microbial pollution of conventional drying. However, it was not able to reduce the moisture content under the recommended value. Still, in many cases, it caused a more stable herb product, than the dried herbs handled by ionizing radiation or the Tyndall-method.

Comparing dried lemon grass an peppermint samples according to the total colony number

\begin{tabular}{|c|c|c|c|c|c|}
\hline Plant & Microbial parameter & $\begin{array}{c}\text { Row samples } \\
C\left(\mathrm{CFU} \mathrm{g}^{-1}\right)\end{array}$ & $\begin{array}{c}\text { Dried herbs } \\
\text { (convęntional drying } \\
C\left(\mathrm{CFU} \mathrm{g}^{-1}\right)\end{array}$ & $\begin{array}{c}\text { Dried herbs } \\
\text { (Tyndall-method) } \\
C\left(\mathrm{CFU} \mathrm{g}^{-1}\right)\end{array}$ & $\begin{array}{l}\text { Commercially } \\
\text { bought, dried herbs }\end{array}$ \\
\hline \multirow[t]{3}{*}{ Lemon grass } & Total colony number & $2.9 \times 10^{5}$ & $1 \times 10^{5}$ & $2.3 \times 10^{6}$ & $1.7 \times 10^{5}$ \\
\hline & Number of moulds & $9.5 \times 10^{3}$ & $1.1 \times 10^{3}$ & $2 \times 10^{3}$ & $4.9 \times 10^{4}$ \\
\hline & Number of Coliforms & $>1 \times 10^{1}$ & $1.7 \times 10^{6}$ & 0 & $5.7 \times 10^{5}$ \\
\hline \multirow[t]{3}{*}{ Peppermint } & Total colony number & $5.5 \times 10^{5}$ & $5.2 \times 10^{5}$ & $6 \times 10^{4}$ & $6 \times 10^{5}$ \\
\hline & Number of moulds & $3.1 \times 10^{4}$ & $5.5 \times 10^{4}$ & $2.8 \times 10^{3}$ & $3.25 \times 10^{2}$ \\
\hline & Number of Coliforms & $1.9 \times 10^{2}$ & $1 \times 10^{3}$ & 0 & $1.7 \times 10^{5}$ \\
\hline
\end{tabular}

In case of lemon grass, the conventional drying reduced the total colony number compared to the raw material (see Table 1). The commercially purchased, dried lemon grass had higher colony number, but the difference between the own dried and this sample is not significant. In term of moulds, the lemon grass, which was dried by conventional drying $\left(40^{\circ} \mathrm{C}, 5.5\right.$ hours), had the smallest average colony number. The number 
of coliforms was extremely high, even on the fourth $\left(10^{-4}\right)$ dilution level. Those samples must have suffered some unwanted ambient pollution. However, both the mould and the coliform pollution of the purchased samples were higher, than in the case of conventional dried lemon grass, the raw herb had the highest total colony number.

By the Tyndall-method the total colony number of this herb was higher, than by the conventional dried samples, although the moisture content was only $8.2 \%$. We observed a slight increase in the number of moulds too.

In the case of peppermint, the lowest colony number was observed by the conventional dried mint sample. Both the raw and the commercially bought dried peppermint have microbial pollution in the same magnitude, and there aren't any significant differences between them. The number of coliforms was relatively high in the commercially purchased peppermint (see Table 1), but the conventional drying method was also favourable for this microorganisms. The raw peppermint contained the lowest amount of coliform. Its number was smaller than the ionizing radiation treated, dried peppermint's with three magnitudes. The total colony number was also lower in the raw peppermint than in the commercially purchased mint, but the number of moulds was higher in the fresh herbs. The number of moulds was higher in the conventional dried herbs and exceeded the amount of the purchased one's with two magnitudes.

Using Tyndall-drying method seems more effective by reducing the microbial pollution, than conventional drying in the case of peppermint. The total colony number of this sample decreased to $6 \times 10^{4} \mathrm{CFU} \mathrm{\textrm {g } ^ { - 1 }}$ compared to the other dried mint sample $\left(5.2 \times 10^{5}\right.$ CFU $\mathrm{g}^{-1}$ ), and there was a magnitude difference between the average colony number of moulds $\left(2.8 \times 10^{3}\right.$ CFU g ${ }^{-1}$ instead of $5.3 \times 10^{4} \mathrm{CFU} \mathrm{g}^{-1}$ ).

The microbial pollution of the commercial purchased, dried peppermint $\left(5.95 \times 10^{5} \mathrm{CFU} \mathrm{g}^{-1}\right)$ was worse than the total colony number of the acquired, dried lemon grass $\left(5.5 \times 10^{5} \mathrm{CFU} \mathrm{g}^{-1}\right)$. Still the lemon grass had larger amount of coliforms and moulds.

We did disk-diffusion agar test with Geobacillus stearothermophilus, but none of the herbs caused an inhibitory zone. The treated, the untreated herbs and even the raw and the bulk milk were also tested for Clostridium and Salmonella spp., but no growth was observed in the samples.

According to the microbial assessment, our final, herby products were unable for human consumption. We cannot count the total colony number on the Plate Count plates, because of the number of the colonies exceeded 300 from the first $\left(10^{-1}\right)$ to the fourth $\left(10^{-4}\right)$ dilution, so we cannot take them into account.

The number of coliforms also was too high to estimate and in the samples, which contained herbs dried by us also contained Escherichia coli, but in the blank cheese and in the commercial herbs didn't contain this bacteria.

In every cheese samples grown mesophilic sporeforming Clostridium, but their colony number was extremely high in the blank cheese and in the sample, which contained lemon grass dried by us.

The magnitude of mould pollution of the cheeses was about $10^{1} \mathrm{CFU} \mathrm{g}^{-1}$, until the mean average number of the yeasts was higher with at two scales $\left(10^{3} \mathrm{CFU} \mathrm{g}^{-1}\right)$.

The average sample, we mixed from the cheese samples and even the pasteurized, unified milk was Salmonella positive. However none of their black colonies was grown on the XLD media, but the serotyping with $\mathrm{O}$-antigen confirmed the presence of the Salmonella spp. We needed to destroy our samples after the first assessment.

\section{CONCLUSIONS}

Humanity still commonly use herbs and spices for health care, flavouring, creating cosmetics and preservation. If there is an option to extract unknown or new chemical components from herbs, which has an antimicrobial effect against the pathogens, using them could be beneficial against the drug-resistant strains.

The market for dairy products is a dynamically improving sector of the food industry and the quarter of its wide range of products are different kind of cheeses. With the addition of herbs to cheeses, potential, functional dairy product can be produced. The added herbs would affect the organoleptic properties of the cheeses, but also could decrease the numbers of the pathogens or spoilage microorganisms, so widening the storage-life as natural preservatives.

To ensure the required microbial safety of herbs, we need to reduce their microbial pollution. Convective drying is a commonly used method for the preservation of herbs by decreasing their moisture content under 10 $\%$ MC. The efficiency could be increased by raising the drying temperature, but it also could cause changes in the chemical structures of the active components or degrade them.

The quality of the final product needs to meet the requirements of the referred regulation (like Decree 4/1998. (XI.11.) EüM), and to the expectations of the consumers, and at the same time, it needs to be safe for human consumption.

In this research, we used lemon grass and peppermint dried by us using Tyndall-method, and the same herbs purchased commercially, dried by ionizing radiation to create potential functional food from our cheeses. Because of the microbial instability caused by the drying method of herbs, our final products had a high amount of plant originated microorganisms. The cheeses were nutrient-rich media for their growth.

In our final products the number of coliforms, mesophilic spore-forming bacteria and Escherichia coli exceeded the limit of microbiological safety. Furthermore, we also indicated the presence of Salmonella spp. in the cheeses, so we needed to stop our measurements with our samples immediately. These products were unable for human consumption.

Creating a functional food by the addition of herbs or spices, the manufacturer will meet several challenges in terms of the microbiological safety of the final 
product. For us, further researches are required to enhance our cheese technology, and it might be more appropriate to use herb extracts instead of the herbs.
Instead of convective drying, we need to use complex drying methods or microwave drying, and higher pasteurization temperature and time.

\section{REFERENCES}

4/1998. [XI. 11.] EüM rendelet: 1. számú melléklet - Élelmiszerek mikrobiológiai vizsgálata és megítélése; 2 . számú melléklet - Az élelmiszer megítélését befolyásoló kórokozók; 4. számú melléklet - Az élelmiszer-előállitás belső minőségellenőrzését szolgáló mikrobiológiai vizsgálatok és ajánlott határértékek. [https://net.jogtar.hu/jogszabaly?docid=99800004.eum]

Arslan, D.-Özcan, M. M.-Menges, H. O. (2010): Evaluation of drying methods with respect to drying parameters, some nutritional and colour characteristics of peppermint [Mentha $x$ piperita L.]. Energy Conversion and Management. 51: 27692775.

Aschwanden, C. (2001): Herbs for the health, but how safe are they? Bulletin of the World Health Organization. 79[7]: 691-692.

Borbélyné, H .É.-Kutasy, E. (2012): Gyógynövények termesztése és feldolgozása jegyzet. Debreceni Egyetem.

Chua, L. Y. W.-Chong, C. H.-Chua, B. L.-Figel, A. (2019): Influence of drying methods on the antibacterial, antioxidant and essential oil volatile consumption of herbs: a review. Food and Bioprocess Technology. 12: 450-476.

Díaz-Maroto, M. C.-Pérez-Coello, M. S.-Vínas, M. A. G.Cabezudo, M. D. (2003): Influence of drying on the flavor quality of spearmint [Mentha spicata L.]. Journal of Agricultural and Food Chemistry. 51: 1265-1269. https://doi.org/10.21/jf020805I

El-Sayed, S. M.-Youssef, A. M. (2019): Potential application of herbs and spices and their effects in functional dairy products. Heliyon. 5: 1-7.

European Parliament and Council (2008): Regulation [EC] No 1334/2008 of the European Parliament and of the Council of 16 December 2008 on flavourings and certain food ingredients with flavouring properties for the use in and on foods and amending Council Regulation [EEC] No 1601/91, Regulations EC.Official Journal of the European Union.
Ghasemi, M.-Jafarpour, M.-Mortazeinezhad, F. (2013): Effect of different drying methods on the quality and quantity of the essential oil of lemon balm [Melissa officinalis L.]. International Journal of Agriculture and Crop Sciences. 6[9]: 501-50.

Granato, D.-Santos, J. S.-Salem, D. S.-Mortazavian, A. M.-Rocha, R. S.-Cruz, A. G. (2018): Effects of herbal extracts on quality traits of yogurts, cheeses, fermented milks, and ice creams: a technological perspective. Current Opinion in Food Science. 19: $1-7$.

Lee, N. K.-Jeewanthi, R. K. C.-Park, E. H.-Paik, H. D. (2016): Psysicochemical and antioxidant properties of Cheddar-type cheese fortified with Inula britannica extract. Journal of Dairy Sciences. 99: 83-88.

Mimica-Dukic, N.-Bozin, B.-Sokovic, M.-Simin, N. (2004): Antimicrobial and antioxidant activities of Melissa officinalis $\mathrm{L}$. [Lamiaceae] essential oil. Journal of Agricultural and Food Chemistry. 52: 2485-2489.

PM Food and Dairy Consulting (2014): World cheese market report 2000-2020. 7: 13-32.

Rocha, R. P.-Melo, E. C.-Radünz, L. L. (2011): Influence of drying process on the quality of medicinal plants: A review. Journal of Medicinal Plants Research. 5[33]: 7076-7084.

Rubinskiené, M.-Viskelis, P.-Dambrauskiené, E.-Viskelis, J.Karkleliené, R. (2015): Effect of drying methods on the chemical consumption and colour of peppermint [Mentha x piperita L.] leaves. Zemdirbyste-Agriculture. 102[2]: 223-228.

Shan, B.-Cai, Y. Z.-Brooks, J. D.-Corke, H. (2001): Potential application of spice and herb extracts as natural preservatives in cheese. Journal of Medicinal Food. 14: 284-290.

Therdthai, N.-Zhou, W. (2009): Characterization of microwave vacuum drying and hot air drying of mint leaves [Mentha cordifolia Opiz ex Fresen]. Journal of Food Engineering. 91: 482-489. 
